\title{
Epithelial-mesenchymal transition was identified as a potential marker for breast cancer aggressiveness using reverse transcription-quantitative polymerase chain reaction
}

\author{
ULRICH ANDERGASSEN, KRISTINA SCHLENK, UDO JESCHKE, HARALD SOMMER and ALEXANDRA KÖLBL
}

Department of Gynecology and Obstetrics, LMU Munich, D-80337 Munich, Germany

Received July 17, 2017; Accepted November 11, 2017

DOI: $10.3892 / \mathrm{mmr} .2018 .9091$

\begin{abstract}
The primary cause of breast cancer-associated mortality is the formation of distant metastasis. During the metastatic process, single tumor cells dissolve from the primary tumor site and undergo various changes in cell adhesion and motility properties. The tumor cells invade the blood stream and travel to different sites of the body, where they may initiate outgrowth. These cells are referred to as circulating tumor cells (CTCs). The process of changing cellular properties is known as epithelial to mesenchymal transition (EMT). As a different set of genes is upregulated during EMT, such genes may serve as marker genes for the detection of CTCs based on reverse transcription-quantitative polymerase chain reaction (RT-qPCR). Therefore, EMT- and breast cancer-related genes were selected as RT-qPCR markers. These genes were tested for performance in a model system of blood samples from healthy donors, to which a number of various breast cancer cell lines were added. The genes with optimal performance were subsequently used in RT-qPCR with 35 breast cancer patient samples. The genes which showed the highest and most consistent increase in gene expression with the increase in the number of cancer cell line cells added were CK19, Snail, FoxC2 and Twist. Following RT-qPCR for all patient samples, two subgroups were arranged: One group in which all genes were downregulated and the second group with at least one gene indicated an upregulation of gene expression. Comparisons were made between the tumour characteristics from these two groups. Results suggested that carcinomas of the first group exhibited a less aggressive tumor biology compared with those in the second group. The present study indicated a novel RT-qPCR based test for tumor malignancy.
\end{abstract}

Correspondence to: $\mathrm{Dr}$ Alexandra Kölbl, Department of Gynecology and Obstetrics, LMU Munich, Maistrasse 11, D-80337 Munich, Germany

E-mail: alexandra.koelbl@med.uni-muenchen.de

Key words: breast cancer, epithelial to mesenchymal transition, circulating tumor cells, real-time polymerase chain reaction, tumor aggressiveness, gene expression

\section{Introduction}

Breast cancer is, although diagnosis and treatment improved a lot in the past years still the most frequent malignancy and causes the most cancer-related death in women worldwide. Thereby it is not the primary tumor itself, which is deathly, but the outgrowth of remote metastases, devastating vital organs. The mechanisms leading to metastasis formation had been investigated and described in detail (1): Single tumor cells detach from the primary tumor mass, enter blood vessels and travel throughout the body via blood stream. When they leave circulation, they can settle in remote spaces of the body and are considered to be the seed for metastatic outgrowth (2). As long as these detached cells are in the blood they are called circulating tumor cells (CTCs) (3-5), but if these CTCs manage to invade bone marrow, they turn to be 'DTCs', disseminated tumor cells, which can even form tumor reservoirs within the bone marrow (6-10). It had been shown, that the occurrence of CTCs/DTCs strongly influences patients' prognosis towards a worse outcome $(5,10-12)$.

The most important step in the formation of CTCs/DTCs is a process called epithelial to mesenchymal transition (EMT). During EMT the epithelial tumor cells change their phenotypical characteristics like cell adhesion and motility, acquire invasiveness and loose epithelial markers (13-15). At the end of the EMT process, it gets hard to recognize these cells as tumor cells, because they adopt a mesenchymal-like appearance $(16,17)$. But the EMT process is reversible, and as the cells leave the circulation to establish metastatic outgrowth in a different organ, mesenchymal to epithelial transition (MET) takes place (18-20).

Here we report a reverse transcription-quantitative polymerase chain reaction (RT-qPCR) based approach for the detection of CTCs from patient blood samples, using EMT-associated genes as PCR targets. The genes, which are described in the following get upregulated, when EMT process is started, but are not upregulated in normal mesenchymal cells like blood cells, so they can be detected by RT-qPCR even in a background of white blood cells (for this reason Vimentin, which is a frequently described EMT-marker was not included in our analysis, as it is also upregulated in normal blood cells). We decided to concentrate on the following genes: Cytokeratin 19, which is also used in the immunohistochemical detection of cancer cells (APAAP-staining) $(21,22)$ and is 
a marker for shorter disease free survival and reduced overall survival in breast cancer patients (23-26). Furthermore it is especially expressed in metastatic breast cancer cells $(27,28)$ and was already used as a biomarker for CTCs in the blood of breast cancer patients (29). Furthermore CK19 was shown to be expressed in CTCs from early and metastatic breast cancer patients, together with the EMT-markers Twist and Vimentin (30), so it could be concluded, that this epithelial marker is not downregulated by EMT. Snail is a zinc-finger domain transcription factor, which is known to trigger EMT by repression of E-cadherin expression (31-33). It is upregulated in recurrent tumors (34), provokes loss of epithelial markers (33) and is regarded as a marker of metastatic potential (31). Slug also represses E-cadherin expression (35), but snail and slug have a non-equivalent role in EMT and need different cofactors for DNA binding (36). Additionally, Snail and Slug seem to have high expression levels in early and metastatic breast cancer patients (30). FoxC2 is also a transcription factor and is involved in tumor relapse and metastasis formation $(37,38)$. Slug and FoxC2 are in turn upregulated by snail and twist and are another driving force for EMT (39). FoxC2 is induced during the EMT process, promotes mesenchymal differentiation (40) and is also involved in angiogenesis (41). Together with Twist, FoxC2 is associated with grading and a shorter time to recurrence (38). Twist in turn regulates cell migration, a knockdown results in reduced cell migration and invasion (42), and EMT is induced more moderately (43). Twist also seems to play a role in metastasis formation (44) and is regulated by the $\mathrm{Wnt} / \beta$-catenin pathway (45). Snail and Twist are regarded as inducers for EMT process, (39) are misregulated in breast cancer and correlate with poor clinical outcomes $(46,47)$. Furthermore Twist upregulates the expression of the proto-oncogene Akt2 (48). Akt2 in turn upregulates integrin-expression (49), leading to an enhanced EMT-like morphological conversion (50), increased migration and invasion and resistance to Paclitaxel (48). ALDH1, last but not least, was described as marker for EMT, which has elevated expression levels in breast cancer patients $(46,51)$, is a marker of stem cells and contributes to a poorer prognosis (52). It is associated with a larger tumor size, higher grading and the occurrence of lymph node metastasis, and hence is related to a more aggressive phenotype and a poorer prognosis (53-55). ALDH1, Twist and Akt2 were especially found to be upregulated in a group of CTC-positive breast cancer patients (56).

These genes were first analysed in an artificially created model system: Blood samples from healthy donors were withdrawn and breast cancer cell line cells (MCF-7 and MDA-MB231) were added in certain amounts $(0-1,000$ cells $/ \mathrm{ml}$ blood sample). The samples were processed just like the patient samples and RT-qPCR was carried out with all selected marker genes. The genes which performed best in this model system were then used in the patients RT-qPCR, so that precious patient material could be saved. The genes for Cytokeratin 19 (CK19), Snail, FoxC2 and Twist were then used to analyse 35 patient samples, which were selected randomly. After analysis of the RT-qPCR experiments patient samples could be divided into two subgroups: in the first group all genes were downregulated, in the second group at least one gene had an RQ-value greater than 1, meaning that the gene is upregulated. In the comparison of the samples from the two groups it could be seen, that the subgroup of only downregulated genes consisted of less aggressive tumors while in the group, in which at least one of the marker genes was upregulated, tumours had a more aggressive tumor biology, what means, that RT-qPCR analysis of those 4 genes could already give a hint towards tumor aggressiveness.

\section{Materials and methods}

Model system samples. As a model system blood samples from healthy donors (all female, average age of 35 years) were withdrawn and processed as described for the patient blood samples, but before addition of TRIzol LS reagent (Invitrogen; ThermoFisher Scientific, Darmstadt, Germany) a certain number (10/100/1,000 per ml blood sample) of breast cancer cell line cells were added (both cell lines used were added to the blood sample in equal parts). Breast cancer cell lines which were used in the experiments were MCF-7 (ATCC: HTB-22) and MDA-MB-231 (ATCC: HTB-26). The cells were subcultured as described in the ATCC product sheet and counted with a Neubauer improved counting chamber to determine exact amounts which had to be added to the blood samples.

Patients. Written consent was received from 35 patients included in the study and conformed to the declaration of Helsinki. Furthermore, ethical approval was received from the ethics committee of LMU Munich (Munich, Germany) (LMU 148-12). $20 \mathrm{ml}$ blood were withdrawn from each patient and processed as described. RT-qPCR was performed on the patient samples and afterwards patient samples could be divided in two subgroups depending on gene expression values. Patient characteristics (as completely as possible) are shown in Table I.

Blood samples. A total of $20 \mathrm{ml}$ blood were withdrawn from each patient and from some healthy volunteers and diluted with PBS to $30 \mathrm{ml}$. To enrich the leucocyte/CTC-fraction a density gradient centrifugation was carried out. Therefore the blood samples were layered onto $20 \mathrm{ml}$ of Histopaque 1,077 (Invitrogen; ThermoFisher Scientific) and centrifuged at $400 \mathrm{x}$ g for $25 \mathrm{~min}$ at room temperature. Afterwards the buffy coat was aspirated carefully, transferred into a fresh tube and washed with PBS by centrifuging at $250 \mathrm{x}$ g for $10 \mathrm{~min}$ at $4^{\circ} \mathrm{C}$. Supernatant was discarded and the cell pellet containing leucocytes and CTCs was stored at $80^{\circ} \mathrm{C}$ until further processing.

RNA isolation. For RNA isolation the cell pellets were dewed and resuspended in $1 \mathrm{ml}$ Trizol LS reagent. 0,2 $\mathrm{ml}$ Chloroform (Merck KGaA, Darmstadt, Germany) were added, samples were vortexed vigorously and subsequently centrifuged at $12,000 \mathrm{x} \mathrm{g}$ and $4^{\circ} \mathrm{C}$ for $15 \mathrm{~min}$. After centrifugation the clear upper phase was carefully aspired and transferred into a fresh Eppendorf tube. A total of $0,5 \mathrm{ml}$ isopropanol (Merck KGaA) were added and samples were placed at $-20^{\circ} \mathrm{C}$ overnight. The next day the samples were centrifuged at $12,000 \mathrm{x} \mathrm{g}, 4^{\circ} \mathrm{C}$ for 10 min. to precipitate RNA. Supernatant was removed and RNA-pellet was washed with $75 \%$ ethanol (Merck KGaA) and centrifugation at $12,000 \mathrm{x} \mathrm{g}$ and $4^{\circ} \mathrm{C}$ for $10 \mathrm{~min}$. Supernatant was removed again and RNA-pellet was air dried before it was resuspended in RNase-free water. RNA concentration 
Table I. Patient subgroups and tumor characteristics.

\begin{tabular}{|c|c|c|c|c|c|c|c|c|c|}
\hline $\begin{array}{l}\text { No. of } \\
\text { sample }\end{array}$ & Age & $\begin{array}{l}\text { Tumor } \\
\text { size }\end{array}$ & $\begin{array}{l}\text { Nodal } \\
\text { state }\end{array}$ & $\begin{array}{l}\text { Metasasis } \\
\text { state }\end{array}$ & Grading & $\begin{array}{c}\text { ER } \\
\text { state }(\%)\end{array}$ & $\begin{array}{c}\mathrm{PR} \\
\text { state }(\%)\end{array}$ & $\begin{array}{l}\text { Her2 } \\
\text { state }\end{array}$ & $\begin{array}{c}\text { Menopausal } \\
\text { state }\end{array}$ \\
\hline 1 & 62 & pT1b (8 mm) & pN0 (0/1) & $\mathrm{pMx}$ & G1 & 80 & 60 & neg & post \\
\hline 2 & 50 & pT1b (8 mm) & pNO $(0 / 5)$ & $\mathrm{pMx}$ & G1 & 80 & 95 & neg & pre \\
\hline 3 & 73 & pT1c (13 mm) & pN0 (0/2) & $\mathrm{pM} 0$ & G1 & 99 & 99 & neg & post \\
\hline 4 & 54 & pT1c (13 mm) & pN0 (0/3) & $\mathrm{pMx}$ & G1 & 100 & 100 & neg & climact \\
\hline 5 & 72 & pT2 (35 mm) & pN1a $(3 / 12)$ & pM0 & G1 & 90 & 90 & neg & post \\
\hline 6 & 72 & cT1b $(8,6)$ & $\mathrm{pNx}$ & $\mathrm{pMx}$ & G1 & 90 & 80 & neg & post \\
\hline 7 & 82 & pT1b (7 mm) & pN0 (0/6) & $\mathrm{pMx}$ & G3 & 75 & 0 & pos & post \\
\hline 8 & 67 & pT1b (8 mm) & pN0 (0/1) & $\mathrm{pMx}$ & G3 & 95 & 90 & neg & post \\
\hline 9 & 48 & pT1b (9 mm) & pN0 (0/1) & $\mathrm{pMx}$ & G3 & 0 & 0 & neg & n.a. \\
\hline 10 & 65 & pT1c & pNO (0/3) & $\mathrm{pMx}$ & G3 & 85 & 85 & pos & n.a. \\
\hline 11 & 73 & pT1c (14 mm) & pN0 (0/1) & pM0 & G3 & 80 & 80 & neg & post \\
\hline 12 & 35 & pT1c (14 mm) & pN0 (0/4) & $\mathrm{pMx}$ & G3 & 10 & 10 & neg & pre \\
\hline 13 & 65 & pT2 (34 mm) & pN1 (1/2) & pM0 & G3 & 99 & 15 & neg & post \\
\hline 14 & 62 & pT1c (12 mm) & pNO (0/3) & $\mathrm{pMx}$ & $\mathrm{G} 2$ & 100 & 100 & neg & n.a. \\
\hline 15 & 48 & pT1c (14 mm) & pN0 (0/2) & pM0 & $\mathrm{G} 2$ & 95 & 95 & neg & pre \\
\hline 16 & 60 & pT2 (22 mm) & pN0 (0/1) & $\mathrm{pMx}$ & G2 & 90 & 15 & n.a & post \\
\hline 17 & 74 & pT3 & pNO (0/8) & pM0 & $\mathrm{G} 2$ & 90 & 90 & neg & post \\
\hline 18 & 49 & pT2 (28 mm) & pN1a $(2 / 2)$ & $\mathrm{pMx}$ & $\mathrm{G} 2$ & 80 & 80 & neg & pre \\
\hline 19 & 65 & pT1c & pN1a $(2 / 19)$ & $\mathrm{pMx}$ & G3 & 100 & 33 & pos & n.a. \\
\hline 20 & 52 & pT1c (19 mm) & pNO (0/1) & pM0 & G3 & 0 & 0 & neg & post \\
\hline 21 & 73 & pT2 (40 mm) & pNO (0/4) & $\mathrm{pMx}$ & $\mathrm{G} 2$ & 75 & 85 & neg & n.a. \\
\hline 22 & 84 & pT1b (8 mm) & pN1a $(1 / 24)$ & pM0 & G2 & 90 & 90 & neg & n.a. \\
\hline 23 & 64 & pT1c (12 mm) & pN1 (1/3) & $\mathrm{pMx}$ & G2 & 100 & 70 & neg & post \\
\hline 24 & 50 & pT1c (14 mm) & pN1a (1/4) & $\mathrm{pMx}$ & G2 & 99 & 99 & neg & n.a. \\
\hline 25 & 51 & pT1c (19 mm) & pN1a (1/1) & $\mathrm{pMx}$ & $\mathrm{G} 2$ & 90 & 90 & neg & pre \\
\hline 26 & 65 & pT2 & pN1a (1/3) & $\mathrm{pMx}$ & G2 & 100 & 100 & neg & n.a. \\
\hline 27 & 75 & pT3 (65 mm) & pN1a (3/3) & pM0 & $\mathrm{G} 2$ & 81 & 81 & neg & post \\
\hline 28 & 60 & pT3 & pN1a $(1 / 11)$ & $\mathrm{pMx}$ & $\mathrm{G} 2-3$ & 100 & 100 & neg & post \\
\hline 29 & 57 & pT4b & pN2a (4/9) & pM1 & G3 & 0 & 0 & neg & n.a. \\
\hline 30 & 54 & pT1c & pN0 (0/11) & pM1 & G3 & n.a. & n.a. & neg & post \\
\hline 31 & 55 & pT1c & pN0 (0/11) & pM1 & G3 & n.a. & n.a. & neg & post \\
\hline 32 & 84 & pT1b (8 mm) & pN1 (1/18) & pM1 & G3 & 70 & 80 & neg & post \\
\hline 33 & 76 & pT3 (63 mm) & pN1a (2/7) & pM1 & n.a. & 90 & 40 & neg & post \\
\hline 34 & 56 & pT2 (22 mm) & $\mathrm{pN} 3 \mathrm{c}$ & pM1 & G3 & 90 & 20 & neg & post \\
\hline 35 & 75 & pyT3 & pN1a $(3 / 12)$ & pM1 & $\mathrm{G} 2$ & 99 & 0 & neg & post \\
\hline
\end{tabular}

n.a., data not available; neg, negative; pos, positive; post, postmenopausal; pre, premenopausal; climact, climacterium; ER, estrogen receptor; Her2, human epidermal growth factor receptor 2; PR, progesterone receptor; pM0, no metastasis detected; pM1, metastasis detected; pMx, no metastases confirmed.

and ratio were measured photometrically (Implen, Munich, Germany) and only RNAs with a ratio between 1,7 and 1,9 were used in further experiments. Additionally RNA integrity was controlled by denaturing gel electrophoresis.

Reverse transcription. For reverse transcription $4 \mu \mathrm{g}$ of the isolated RNA in a max. Volume of $6 \mu 1$ were used. Reverse transcription was carried out with the SuperScript III First Strand Synthesis SuperMix (Invitrogen; ThermoFisher Scientific), according to manufacturer's instructions. In brief: annealing buffer and oligo (dT)-Primers were added to the
RNA and volume was adjusted to $8 \mu \mathrm{l}$ with water. After an incubation at $65^{\circ} \mathrm{C}$ for $5 \mathrm{~min}$ and a short cooling on ice $10 \mu \mathrm{l}$ of $2 \mathrm{X}$ first strand reaction mix and $2 \mu \mathrm{l}$ of the enzyme mix (SuperScriptIII/RNaseOUT) were added and the samples were incubated at $50^{\circ} \mathrm{C}$ for $50 \mathrm{~min}$. Afterwards enzymes were denatured by a 5 -min incubation at $85^{\circ} \mathrm{C}$, then samples could be stored at $-20^{\circ} \mathrm{C}$ until use.

$q P C R$. For qPCR $2 \mu \mathrm{l}$ of the previously generated cDNA of each sample were pipetted into a 96-well qPCR plate and $18 \mu \mathrm{l}$ of a mastermix, consisting of $7 \mu \mathrm{l}$ water, $1 \mu \mathrm{l}$ TaqMan ${ }^{\circledR}$ 
Table II. Reverse transcription-quantitative polymerase chain reaction probes.

\begin{tabular}{llrl}
\hline Probe/Gene & Order no. of probe & Fragment size & \\
\hline 18S & Hs99999901_s1 & $187 \mathrm{bp}$ & Manufacturer \\
GAPDH & Hs03003631_g1 & $69 \mathrm{bp}$ & Thermo Fisher Scientific, Inc. (Waltham, MA, USA) \\
CK19 & Hs00761767_s1 & $116 \mathrm{bp}$ & Thermo Fisher Scientific, Inc. \\
Snail & Hs00195591_m1 & $66 \mathrm{bp}$ & Thermo Fisher Scientific, Inc. \\
Slug & Hs00161904_m1 & $79 \mathrm{bp}$ & Thermo Fisher Scientific, Inc. \\
FoxC2 & Hs00270951_s1 & $102 \mathrm{bp}$ & Thermo Fisher Scientific, Inc. \\
Akt2 & Hs01086099_m1 & $70 \mathrm{bp}$ & Thermo Fisher Scientific, Inc. \\
Twist & Hs01675818_s1 & $85 \mathrm{bp}$ & Thermo Fisher Scientific, Inc. \\
ALDH1 & Hs00946916_m1 & $61 \mathrm{bp}$ & Thermo Fisher Scientific, Inc. \\
\hline
\end{tabular}

PCR-primer (Hydrolysis probes used are listed in Table II; they were not validated, as Applied Biosystems claims a PCR-efficiency of $100 \pm 10 \%$ for their hydrolysis probes) and $10 \mu 1$ 2X RT-PCR reaction mix (Applied Biosystems; Thermo Fisher Scientific, Inc., Waltham, MA, USA) per sample, were added. Every sample was at least analysed as duplicates, $18 \mathrm{~S}$ was used as a reference gene. Negative (water) controls were included. The qPCR reaction was carried out in an Applied Biosystems 7500 fast machine and the following program was run: $95^{\circ} \mathrm{C}$ for $20 \mathrm{sec}$. As an initial denaturation followed by 40 cycles $95^{\circ} \mathrm{C}$ for $3 \mathrm{sec}$ and $60^{\circ} \mathrm{C}$ for $30 \mathrm{sec}$. Increase in fluorescence was measured after every elongation step and thereof gene expression $(\mathrm{RQ}=$ relative quantification) was calculated by the SDS V 1.3.1 software using $2^{-\Delta \Delta \mathrm{Cq}}$ method (57). RQ-values are displayed in Table IIIA and B.

Evaluation. The relative gene expression of every gene in respect to the expression of $18 \mathrm{~S}$ was calculated by the SDS-software. The SDS-files can be displayed in Microsoft ${ }^{\mathrm{TM}}$ Excel $^{\circledR}$, and it was also used to generate graphical data for the model system samples, showing gene expression in dependence on the number of breast cancer cell line cells added to the respective blood sample.

Statistical analysis. All statistical analyses were performed with SPSS v.23 (IBM Corp., Armonk, NY, USA). Kolmogorow-Smirnof-Test was applied to test, if distribution of data was similar. The average RQ-values were compared with the two-tailed t-test and the medians with the Mann-Withney-U-Test.

\section{Results}

Results from model system analysis. The analysis of a model system-blood samples from healthy donors with breast cancer cell line cells added in predefined amounts-was used to decide, which marker genes should be used in the patient samples without wasting precious patient material. The strongest increase in gene expression with increasing number of tumor cells added to the blood samples could be found for CK19. Snail, FoxC2 and Twist also had increasing gene expression values and were therefore selected as marker genes for the analysis of patient samples. The expression

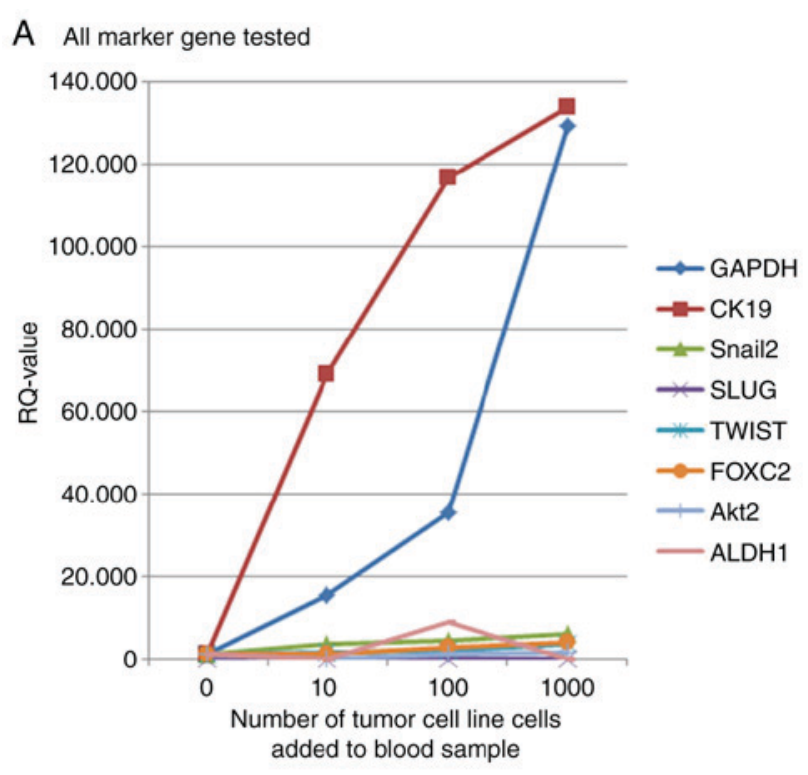

B Enlargement of lower RQ-region

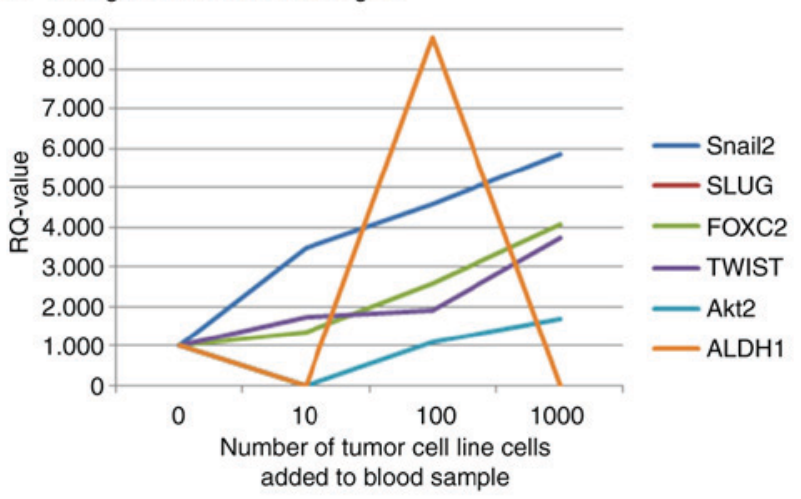

Figure 1. Marker gene expression in model system samples. (A) All marker genes tested; $x$-axis: Number of tumor cells added, y-axis: RQ-value. (B) Enlargement of lower RQ-region; X-axis: Number of tumor cells added, $\mathrm{y}$-axis: RQ-value. RQ, relative gene expression value.

of Slug could not be detected in the qPCR reaction, maybe the Hydrolysis probe was not suitable enough for the probes used in our experiments. ALDH1 showed a decrease in gene expression in the sample with most tumor cells added, so it was also excluded from further analysis. The increase in gene 
Table III. Gene expression values in patient samples.

A, Subgroup of less aggressive tumors with all marker genes downregulated

\begin{tabular}{lcccc}
$\begin{array}{l}\text { No. of sample } \\
\text { (corresponding to } \\
\text { Table I) }\end{array}$ & $\begin{array}{c}\text { RQ } \\
\text { CK19 }\end{array}$ & $\begin{array}{c}\text { RQ } \\
\text { Snail }\end{array}$ & $\begin{array}{c}\text { RQ } \\
\text { FoxC2 }\end{array}$ & $\begin{array}{c}\text { RQ } \\
\text { Twist }\end{array}$ \\
\hline 1 & 0.396 & 0.361 & 0.984 & 0.439 \\
2 & 0.107 & 0.393 & 0.513 & 0.269 \\
3 & 0.334 & 0.152 & 0.829 & 0.566 \\
4 & 0.063 & 0.073 & 0.19 & 0.171 \\
5 & 0.132 & 0.269 & 0.201 & 0.163 \\
6 & 0.011 & 0.183 & 0.031 & 0.024 \\
7 & 0.033 & 0.597 & 0.023 & 0.021 \\
8 & 0.177 & 0.433 & 0.432 & 0.322 \\
9 & 0.021 & 0.354 & 0.102 & 0.132 \\
10 & 0.097 & 0.326 & 0.248 & 0.082 \\
11 & 0.854 & 0.339 & 0.281 & 0.741 \\
12 & 0.073 & 0.216 & 0.17 & 0.164 \\
13 & 0.009 & 0.37 & 0.044 & 0.035 \\
14 & 0.148 & 0.031 & 0.786 & 0.364 \\
15 & 0.131 & 0.078 & 0.648 & 0.334 \\
16 & 0.014 & 0.494 & 0.091 & 0.054 \\
17 & 0.017 & 0.327 & 0.068 & 0.086 \\
18 & 0.16 & 0.787 & 0.703 & 0.567 \\
& & & &
\end{tabular}

B, Subgroup of aggressive tumors with at least one marker gene upregulated

No. of sample

\begin{tabular}{lcrcl}
$\begin{array}{l}\text { (corresponding to } \\
\text { Table I) }\end{array}$ & $\begin{array}{c}\text { RQ } \\
\text { CK19 }\end{array}$ & $\begin{array}{c}\text { RQ } \\
\text { Snail }\end{array}$ & $\begin{array}{c}\text { RQ } \\
\text { FoxC2 }\end{array}$ & $\begin{array}{c}\text { RQ } \\
\text { Twist }\end{array}$ \\
\hline 19 & 0.038 & $\mathbf{1 0 . 7 4 7}$ & 0.15 & 0.181 \\
20 & 0.572 & 0.237 & $\mathbf{1 . 4 7 9}$ & $\mathbf{1 . 0 9}$ \\
21 & 0.401 & $\mathbf{1 5 . 3 8 7}$ & $\mathbf{1 . 9 4 8}$ & $\mathbf{2 . 1 5}$ \\
22 & 0.068 & $\mathbf{1 . 6 3 5}$ & 0.418 & 0.647 \\
23 & 0.027 & $\mathbf{3 . 1 4 3}$ & 0.191 & 0.15 \\
24 & 0.01 & $\mathbf{2 . 1 0 3}$ & 0.062 & 0.056 \\
25 & $\mathbf{1 . 0 3 7}$ & 0.502 & $\mathbf{1 . 6 5 7}$ & $\mathbf{1 . 2 3 1}$ \\
26 & $\mathbf{1 . 2 5 1}$ & $\mathbf{1 . 0 0 7}$ & $\mathbf{4 . 1 1 7}$ & $\mathbf{3 . 7 2}$ \\
27 & $\mathbf{1 . 3 1 5}$ & 0.453 & $\mathbf{2 . 4 8 6}$ & $\mathbf{1 . 6 8 5}$ \\
28 & 0.441 & 0.246 & $\mathbf{2 . 2 3 6}$ & 0.579 \\
29 & $\mathbf{1 . 5 5 5}$ & $\mathbf{2 . 3 0 1}$ & $\mathbf{1 . 0 9 6}$ & 0.945 \\
30 & 0.016 & $\mathbf{1 . 5 6 5}$ & 0.068 & 0.089 \\
31 & 0.491 & $\mathbf{4 . 5 6 6}$ & $\mathbf{1 . 4 3 5}$ & $\mathbf{1 . 6 5}$ \\
32 & 0.094 & $\mathbf{2 . 4 4 2}$ & 0.227 & 0.277 \\
33 & 0.735 & $\mathbf{1 . 9 6 5}$ & $\mathbf{2 . 9 2 2}$ & $\mathbf{2 . 2 2 4}$ \\
34 & 0.038 & $\mathbf{1 . 2 7 9}$ & 0.269 & 0.207 \\
35 & 0.806 & $\mathbf{2 . 0 7 2}$ & $\mathbf{2 . 8 1 8}$ & 0.958 \\
\hline & & & &
\end{tabular}

Bolded items are gene expression values $\geq 1$. RQ, relative gene expression value.
Table IV. Statistical comparison of gene expression values between the two patient groups.

\begin{tabular}{lcccc}
\hline Statistical test & CK19 & Snail & FoxC2 & Twist \\
\hline $\begin{array}{l}\text { Kolmogorow-Smirnof } \\
\text { (data have similar } \\
\text { distribution) }\end{array}$ & 0.018 & 0.000 & 0.002 & 0.002 \\
$\begin{array}{l}\text { Two-tailed t-test } \\
\text { (comparing average }\end{array}$ & 0.008 & 0.007 & 0.002 & 0.002 \\
$\begin{array}{l}\text { values) } \\
\text { Mann-Withney }\end{array}$ & 0.062 & 0.000 & 0.011 & 0.028 \\
$\begin{array}{l}\text { U-Test (comparing } \\
\text { medians) }\end{array}$ & & & & \\
\hline
\end{tabular}

CD19, cluster of differentiation 19.

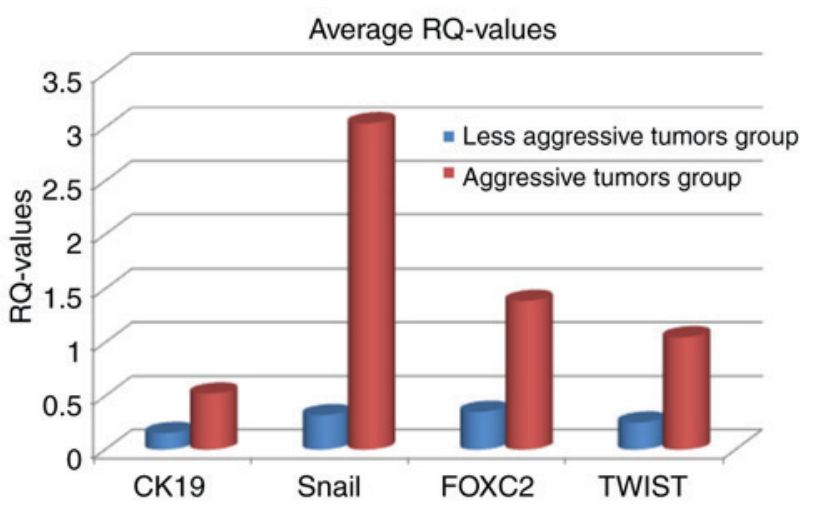

Figure 2. Graphical representation of PCR results from patient probes. RQ-values were averaged over all samples from each subgroup. RQ-values are higher for all four genes in the group of more aggressive tumors (red) in comparison to less aggressive tumor subgroup (blue). (RQ-values are relative gene expression values, calculated by $2^{-\Delta \Delta C q_{-}}$formula). RQ, relative gene expression value.

expression shown by Akt 2 was lower than that seen for Snail, FoxC2 and Twist. Therefore it was decided not to use Akt2 in further experiments. Curves for marker gene expression in artificial model system samples are shown in Fig. 1.

Results from analysis of patient samples. After Real-Time PCR analysis patient samples could be subdivided into two subgroups: In the first group of 18 samples all RQ-values of the used marker genes were below 1, what means, that the genes are downregulated in comparison to the reference sample (Table IIIA). In the second group in contrast, which consisted of 17 samples, at least one of the genes analysed was upregulated, having a RQ-value greater than 1 (Table IIIB). Comparing the subgroups a trend seems to become apparent: Tumors in the first group have a less aggressive biology than the ones in the second subgroup. In the first group some tumors still have a G1-grading (samples 1-6), while in the second group all malignancies have a grading of 2 or more. Furthermore in none of the samples from the first group metastasis formation could be detected, while 7 samples (samples 11-17) of the second group show up with remote metastasis. Also for the nodal status a difference can be seen 
between the two subgroups: while in the first group only three samples have a nodal status of N1 (samples 5, 13 and 18) in the second group only four samples have an N0 status (samples 2, 3,12 and 13), whereas sample No. 2 is a rather large tumor, sample three belongs to the group of aggressive TNBC-tumours and samples 12 and 13 are of the metastatic subcategory. Additionally in the 'less aggressive' category, only one, relatively small, triple-negative tumour can be found (sample 9), while in the second group two triple negative tumours can be found (samples 2 and 11), which also have large tumour sizes, and there are two tumours, for which hormone receptor status was not determined, so it is not sure if they might also be of the rather aggressive TNBC tumor group (samples 12 and 13). Averaging RQ-values of all four genes in both tumor subgroups shows, that RQ-values are higher in the group of aggressive tumors than in the group of less aggressive tumors (Fig. 2). The average and median RQ-values are also statistically significant different between the two groups (Table IV). Only for CK19 the $\mathrm{P}$-values is at a borderline significance level (0.062).

\section{Discussion}

The marker genes, which were used in patient sample analysis are all known as markers for a poor clinical outcome. CK 19 is a marker for metastatic breast cancer $(27,28)$ and late relapse $(26)$, so it is not surprising, that it is upregulated in some of the tumors with aggressive biology, but it still has to be clarified, why it is only upregulated in one of the metastatic breast cancers analysed in our study (sample 11). The other three cases in which it's expression is upregulated have a positive lymph node status, although no coherence between CK19 and lymph node metastasis was shown in the literature. Snail in contrast is upregulated in most aggressive tumor samples, and therefore seems to be a rather important marker. That could be explained by the fact, that snail triggers early events during EMT in it's role as a transcription factor (31-34). Fox C2 is upregulated in more than $50 \%$ of the tumors with aggressive biology ( 9 out of 17), but no coherence between it's function in metastasis formation $(40,41)$ it's correlation with grading (38) and lymph node metastasis could be seen form the results of the presented study. Twist plays a more general role within the EMT process, and is upregulated in 7 out of 17 cases in the on hand study. Therefore it could be concluded, that Twist also plays a basic role in tumor cell transformation, but seems not to be such important as Snail. A special role in metastasis formation (44) could not be confirmed from the experiments presented here.

Taking together these results as a rough conclusion can be said, that tumors, for which all of the four used marker genes are downregulated, have a less aggressive tumor biology than those samples, in which at least one gene is upregulated. But a lot of work confirming this thesis is still necessary. First of all, the analysis should be amplified to a larger group of patient blood samples and the marker gene panel could also be enlarged. It still has to be clarified, in which tumor situation a certain gene is upregulated, and the significance of only one in contrast to two or more upregulated genes has to be elucidated. Differences in gene expression between TNBC-samples should also be enlightened. It can be said, that still lots of work has to be done in this field of research, but the results we present in the on hand study are already giving a certain hint and direction for further research in order to improve diagnostics and refine therapeutical approaches. A further research in this filed could thus help to personalize treatment, thereby reducing side-effects while increasing treatment efficiency, so that research would be rather worth while.

\section{References}

1. Alix-Panabieres $\mathrm{C}$ and Pantel K: Circulating tumor cells: Liquid biopsy of cancer. Clin Chem 59: 110-118, 2013.

2. Bragado P, Sosa MS, Keely P, Condeelis J and Aguirre-Ghiso JA: Microenvironments dictating tumor cell dormancy. Recent Results Cancer Res 195: 25-39, 2012.

3. Andergassen U, Hofmann S, Kölbl AC, Schindlbeck C, Neugebauer J, Hutter S, Engelstädter V, Ilmer M, Friese K and Jeschke U: Detection of tumor cell-specific mRNA in the peripheral blood of patients with breast cancer-evaluation of several markers with real-time reverse transcription-PCR. Int J Mol Sci 14: 1093-1104, 2013

4. Andreopoulou E, Yang LY, Rangel KM, Reuben JM, Hsu L, Krishnamurthy S, Valero V, Fritsche HA and Cristofanilli M: Comparison of assay methods for detection of circulating tumor cells in metastatic breast cancer: AdnaGen adna test breast cancer select/detect versus veridex cell search ${ }^{\mathrm{TM}}$ system. Int J Cancer 130: 1590-1597, 2012.

5. Bednarz-Knoll N, Alix-Panabières $\mathrm{C}$ and Pantel K: Clinical relevance and biology of circulating tumor cells. Breast Cancer Res 13: 228, 2011.

6. Diel IJ, Solomayer EF, Costa SD, Gollan C, Goerner R, Wallwiener D, Kaufmann $M$ and Bastert G: Reduction in new metastases in breast cancer with adjuvant clodronate treatment. N Engl J Med 339: 357-363, 1998.

7. Dowsett $M$ and Dunbier AK: Emerging biomarkers and new understanding of traditional markers in personalized therapy for breast cancer. Clin Cancer Res 14: 8019-8026, 2008.

8. Dowsett M, Procter M, McCaskill-Stevens W, de Azambuja E, Dafni U, Rueschoff J, Jordan B, Dolci S, Abramovitz M, Stoss O, et al: Disease-free survival according to degree of HER2 amplification for patients treated with adjuvant chemotherapy with or without 1 year of trastuzumab: The HERA trial. J Clin Oncol 27: 2962-2969, 2009.

9. Dunnwald LK, Rossing MA and Li CI: Hormone receptor status, tumor characteristics and prognosis: A prospective cohort of breast cancer patients. Breast Cancer Res 9: R6, 2007.

10. Franken B, de Groot MR, Mastboom WJ, Vermes I, van der Palen J, Tibbe AG and Terstappen LW: Circulating tumor cells, disease recurrence and survival in newly diagnosed breast cancer. Breast Cancer Res 14: R133, 2012.

11. Braun S, Vogl FD, Naume B, Janni W, Osborne MP, Coombes RC, Schlimok G, Diel IJ, Gerber B, Gebauer G, et al: A pooled analysis of bone marrow micrometastasis in breast cancer. $\mathrm{N}$ Engl J Med 353: 793-802, 2005.

12. Graves H and Czerniecki BJ: Circulating tumor cells in breast cancer patients: An evolving role in patient prognosis and disease progression. Patholog Res Int 2011: 621090, 2011.

13. Guarino M: Epithelial-mesenchymal transition and tumour invasion. Int J Biochem Cell Biol 39: 2153-2160, 2007.

14. Kölbl AC, Jeschke U and Andergassen U: The significance of epithelial-to-mesenchymal transition for circulating tumor cells. Int J Mol Sci 17: E1308, 2016.

15. Tiwari N, Gheldof A, Tatari M and Christofori G: EMT as the ultimate survival mechanism of cancer cells. Semin Cancer Biol 22: 194-207, 2012.

16. Gorges TM, Tinhofer I, Drosch M, Röse L, Zollner TM, Krahn T and von Ahsen O: Circulating tumour cells escape from EpCAM-based detection due to epithelial-to-mesenchymal transition. BMC Cancer 12: 178, 2012.

17. Raimondi C, Gradilone A, Naso G, Vincenzi B, Petracca A, Nicolazzo C, Palazzo A, Saltarelli R, Spremberg F, Cortesi E and Gazzaniga P: Epithelial-mesenchymal transition and stemness features in circulating tumor cells from breast cancer patients. Breast Cancer Res Treat 130: 449-455, 2011.

18. Hugo H, Ackland ML, Blick T, Lawrence MG, Clements JA, Williams ED and Thompson EW: Epithelial-mesenchymal and mesenchymal-epithelial transitions in carcinoma progression. J Cell Physiol 213: 374-383, 2007.

19. Nieto MA: Epithelial plasticity: A common theme in embryonic and cancer cells. Science 342: 1234850, 2013. 
20. Yao D, Dai C and Peng S: Mechanism of the mesenchymal-epithelial transition and its relationship with metastatic tumor formation. Mol Cancer Res 9: 1608-1620, 2011.

21. Kurec AS, Baltrucki L, Mason DY and Davey FR: Use of the APAAP method in the classification and diagnosis of hematologic disorders. Clin Lab Med 8: 223-236, 1988.

22. Noack F, Schmitt M, Bauer J, Helmecke D, Krüger W, Thorban S Sandherr M, Kuhn W, Graeff H and Harbeck N: A new approach to phenotyping disseminated tumor cells: Methodological advances and clinical implications. Int J Biol Markers 15: 100-104, 2000

23. Ignatiadis M, Kallergi G, Ntoulia M, Perraki M, Apostolaki S Kafousi M, Chlouverakis G, Stathopoulos E, Lianidou E, Georgoulias V and Mavroudis D: Prognostic value of the molecular detection of circulating tumor cells using a multimarker reverse transcription-PCR assay for cytokeratin 19, mammaglobin A and HER2 in early breast cancer. Clin Cancer Res 14 2593-2600, 2008.

24. Ignatiadis M, Xenidis N, Perraki M, Apostolaki S, Politaki E, Kafousi M, Stathopoulos EN, Stathopoulou A, Lianidou E, Chlouverakis G, et al: Different prognostic value of cytokeratin-19 mRNA positive circulating tumor cells according to estrogen receptor and HER2 status in early-stage breast cancer. J Clin Oncol 25: 5194-5202, 2007.

25. Saloustros E and Mavroudis D: CTCs in primary breast cancer (II). Recent Results Cancer Res 195: 187-192, 2012.

26. Saloustros E, Perraki M, Apostolaki S, Kallergi G, Xyrafas A, Kalbakis K, Agelaki S, Kalykaki A, Georgoulias V and Mavroudis D: Cytokeratin-19 mRNA-positive circulating tumor cells during follow-up of patients with operable breast cancer: Prognostic relevance for late relapse. Breast Cancer Res 13: R60, 2011.

27. Soltani S, Mokarian F and Panjehpour M: The expression of CK-19 gene in circulating tumor cells of blood samples of metastatic breast cancer women. Res Pharm Sci 10: 485-496, 2015

28. Zhao S, Yang H, Zhang M, Zhang D, Liu Y, Liu Y, Song Y, Zhang X, Li H, Ma W and Zhang Q: Circulating tumor cells (CTCs) detected by triple-marker EpCAM, CK19 and hMAM RT-PCR and their relation to clinical outcome in metastatic breast cancer patients. Cell Biochem Biophys 65 263-273, 2013

29. Tunca B, Egeli U, Cecener G, Tezcan G, Gökgöz S, Tasdelen I Bayram N, Tolunay S, Umut $\mathrm{G}$, Demirdogen $\mathrm{E}$, et al: CK19, CK20, EGFR and HER2 status of circulating tumor cells in patients with breast cancer. Tumori 98 243-251, 2012.

30. Kallergi G, Papadaki MA, Politaki E, Mavroudis D, Georgoulias V and Agelaki S: Epithelial to mesenchymal transition markers expressed in circulating tumour cells of early and metastatic breast cancer patients. Breast Cancer Res 13: R59, 2011.

31. Blanco MJ, Moreno-Bueno G, Sarrio D, Locascio A, Cano A, Palacios J and Nieto MA: Correlation of Snail expression with histological grade and lymph node status in breast carcinomas. Oncogene 21: 3241-3246, 2002.

32. Peinado H, Olmeda D and Cano A: Snail, Zeb and bHLH factors in tumour progression: an alliance against the epithelial phenotype? Nat Rev Cancer 7: 415-428, 2007.

33. Vega S, Morales AV, Ocaña OH, Valdés F, Fabregat I and Nieto MA: Snail blocks the cell cycle and confers resistance to cell death. Genes Dev 18: 1131-1143, 2004.

34. Moody SE, Perez D, Pan TC, Sarkisian CJ, Portocarrero CP, Sterner CJ, Notorfrancesco KL, Cardiff RD and Chodosh LA: The transcriptional repressor Snail promotes mammary tumor recurrence. Cancer Cell 8: 197-209, 2005

35. Hajra KM, Chen DY and Fearon ER: The SLUG zinc-finger protein represses E-cadherin in breast cancer. Cancer Res 62 : $1613-1618,2002$

36. Villarejo A, Cortes-Cabrera A, Molina-Ortiz P, Portillo F and Cano A: Differential role of Snaill and Snail2 zinc fingers in E-cadherin repression and epithelial to mesenchymal transition. J Biol Chem 289: 930-941, 2014

37. Dai J, Wang JY, Yang LL, Xiao Y, Qu ZL, Qin SH and Ruan QR Correlation of Forkhead Box c2 with subtypes and invasive ability of invasive breast cancer. J Huazhong Univ Sci Technolog Med Sci 34: 896-901, 2014

38. Lim JC, Koh VC, Tan JS, Tan WJ, Thike AA and Tan PH: Prognostic significance of epithelial-mesenchymal transition proteins Twist and Foxc2 in phyllodes tumours of the breast. Breast Cancer Res Treat 150: 19-29, 2015
39. Taube JH, Herschkowitz JI, Komurov K, Zhou AY, Gupta S, Yang J, Hartwell K, Onder TT, Gupta PB, Evans KW, et al: Core epithelial-to-mesenchymal transition interactome gene-expression signature is associated with claudin-low and metaplastic breast cancer subtypes. Proc Natl Acad Sci USA 107: 15449-15454, 2010.

40. Mani SA, Yang J, Brooks M, Schwaninger G, Zhou A, Miura N, Kutok JL, Hartwell K, Richardson AL and Weinberg RA: Mesenchyme forkhead 1 (FOXC2) plays a key role in metastasis and is associated with aggressive basal-like breast cancers. Proc Natl Acad Sci USA 104: 10069-10074, 2007.

41. Kume T: Foxc2 transcription factor: A newly described regulator of angiogenesis. Trends Cardiovasc Med 18: 224-228, 2008.

42. Finlay J, Roberts CM, Lowe G, Loeza J, Rossi JJ and Glackin CA: RNA-based TWIST1 inhibition via dendrimer complex to reduce breast cancer cell metastasis. Biomed Res Int 2015: 382745, 2015.

43. Tang H, Massi D, Hemmings BA, Mandalà M, Hu Z, Wicki A and Xue G: AKT-ions with a TWIST between EMT and MET. Oncotarget 7: 62767-62777, 2016.

44. Yang J, Mani SA, Donaher JL, Ramaswamy S, Itzykson RA, Come C, Savagner P, Gitelman I, Richardson A and Weinberg RA: Twist, a master regulator of morphogenesis, plays an essential role in tumor metastasis. Cell 117: 927-939, 2004.

45. Watanabe O, Imamura H, Shimizu T, Kinoshita J, Okabe T, Hirano A, Yoshimatsu K, Konno S, Aiba M and Ogawa K: Expression of twist and wnt in human breast cancer. Anticancer Res 24: 3851-3856, 2004.

46. Giordano A, Gao H, Anfossi S, Cohen E, Mego M, Lee BN, Tin S, De Laurentiis M, Parker CA and Alvarez RH: Epithelial-mesenchymal transition and stem cell markers in patients with HER2-positive metastatic breast cancer. Mol Cancer Ther 11: 2526-2534, 2012.

47. Micalizzi DS, Farabaugh SM and Ford HL: Epithelial-mesenchymal transition in cancer: Parallels between normal development and tumor progression. J Mammary Gland Biol Neoplasia 15: 117-134, 2010.

48. Cheng GZ, Chan J, Wang Q, Zhang W, Sun CD and Wang LH: Twist transcriptionally up-regulates AKT2 in breast cancer cells leading to increased migration, invasion and resistance to paclitaxel. Cancer Res 67: 1979-1987, 2007.

49. Arboleda MJ, Lyons JF, Kabbinavar FF, Bray MR, Snow BE, Ayala R, Danino M, Karlan BY and Slamon DJ: Overexpression of AKT2/protein kinase Bbeta leads to up-regulation of beta1 integrins, increased invasion, and metastasis of human breast and ovarian cancer cells. Cancer Res 63: 196-206, 2003.

50. Irie HY, Pearline RV, Grueneberg D, Hsia M, Ravichandran P, Kothari N, Natesan S and Brugge JS: Distinct roles of Akt1 and Akt2 in regulating cell migration and epithelial-mesenchymal transition. J Cell Biol 171: 1023-1034, 2005.

51. Kasimir-Bauer S, Hoffmann O, Wallwiener D, Kimmig R and Fehm T: Expression of stem cell and epithelial-mesenchymal transition markers in primary breast cancer patients with circulating tumor cells. Breast Cancer Res 14: R15, 2012.

52. Ginestier C, Hur MH, Charafe-Jauffret E, Monville F, Dutcher J, Brown M, Jacquemier J, Viens P, Kleer CG, Liu S, et al: ALDH1 is a marker of normal and malignant human mammary stem cells and a predictor of poor clinical outcome. Cell Stem Cell 1: 555-567, 2007.

53. Liu Y, Lv DL, Duan JJ, Xu SL, Zhang JF, Yang XJ, Zhang X, Cui YH, Bian XW and Yu SC: ALDH1A1 expression correlates with clinicopathologic features and poor prognosis of breast cancer patients: A systematic review and meta-analysis. BMC Cancer 14: 444, 2014

54. Morimoto K, Kim SJ, Tanei T, Shimazu K, Tanji Y, Taguchi T, Tamaki Y, Terada N and Noguchi S: Stem cell marker aldehyde dehydrogenase 1-positive breast cancers are characterized by negative estrogen receptor, positive human epidermal growth factor receptor type 2 and high Ki67 expression. Cancer Sci 100: 1062-1068, 2009.

55. Pan H, Wu N, Huang Y, Li Q, Liu C, Liang M, Zhou W, Liu X and Wang S: Aldehyde dehydrogenase 1 expression correlates with the invasion of breast cancer. Diagn Pathol 10: 66, 2015.

56. Aktas B, Tewes M, Fehm T, Hauch S, Kimmig R and Kasimir-Bauer S: Stem cell and epithelial-mesenchymal transition markers are frequently overexpressed in circulating tumor cells of metastatic breast cancer patients. Breast Cancer Res 11: R46, 2009.

57. Livak KJ and Schmittgen TD: Analysis of relative gene expression data using real-time quantitative PCR and the 2(-Delta Delta $\mathrm{C}(\mathrm{T})$ ) method. Methods 25: 402-408, 2001 